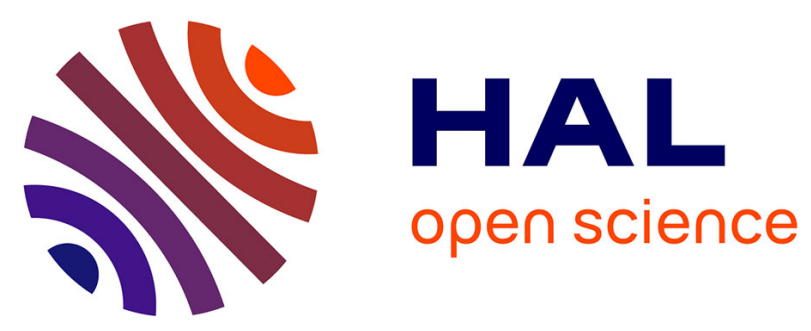

\title{
Selling One's Property on an Informal Settlement: A Praxeological Approach to a Syrian Case Study
}

\author{
Baudouin Dupret, Myriam Ferrier
}

\section{To cite this version:}

Baudouin Dupret, Myriam Ferrier. Selling One's Property on an Informal Settlement: A Praxeological Approach to a Syrian Case Study. Popular Housing and Urban Land Tenure in the Middle East: Case Studies from Egypt, Syria, Jordan, Lebanon and Turkey (M. Ababsa et al., eds., American University in Cairo Press), 2012. hal-02615687

\section{HAL Id: hal-02615687 https://hal.science/hal-02615687}

Submitted on 23 May 2020

HAL is a multi-disciplinary open access archive for the deposit and dissemination of scientific research documents, whether they are published or not. The documents may come from teaching and research institutions in France or abroad, or from public or private research centers.
L'archive ouverte pluridisciplinaire HAL, est destinée au dépôt et à la diffusion de documents scientifiques de niveau recherche, publiés ou non, émanant des établissements d'enseignement et de recherche français ou étrangers, des laboratoires publics ou privés. 


\section{SELLING ONE'S PROPERTY ON AN INFORMAL SETTLEMENT A Praxeological Approach to a Syrian Case Study}

Baudouin Dupret (CNRS/ISP)

Myriam Ferrier (IFPO)

This chapter addresses the issue of how real estate transactions are organized in Damascus, in socalled informal neighbourhoods, i.e. city quarters which developed by violating the law on rural lands theoretically improper for development. There are many different practices, which may look random, yet they are shaped through a complex relationship to the law, which acknowledges the existence of informal neighbourhoods, called mukhalafat in Arabic, in different ways. We shall describe this relationship through one single case study, by analyzing documents kept by the buyer of a property: Mrs. Sabbah.

The flat Mrs. Sabbah bought is located in the Palestinian refugee camp Mukhayyam al-Yarmuk. The status of its real-estate property is subject to rules different from those of other Damascus neighbourhoods. For the Land Registry Department, this land is registered as rural and belongs to the northern region of the United Arab Republic. A specific department was created in the 1940s to administer affairs related to Palestinian refugees: the Foundation for Palestinian Refugees (al-Mu'assasa li-l-laji'in al-filastiniyyin). Among its responsibilities is the administration of land in the Yarmuk area on which it has a 99 year leasehold. It is responsible for the parcelling out of the land and for its allotment to Palestinian refugees. In parallel, the municipality (baladiyya), also called the Local Council, is responsible for the issuing of building permits and the registration of house tenancy contracts.

Most of the documents consulted concern real estate transactions on different properties located within the same building, on al-Ja'awna street, in the historical heart of the Camp, on a parcel containing around one hundred buildings. The specific building we are dealing with, which is not registered in the Land Registry, was built in several stages. The initial construction comprised a ground-floor and one storey. Today, the building has four storeys. The documents kept by Mrs. Sabbah and the relating real estate transactions explain how many storeys were added to the building and how they were sold. Mrs. Sabbah's file also includes water and electricity bills plus one house tenancy contract.

These documents can be analyzed in two ways. First, we shall see how they describe the property for specific practical purposes and how, therefore, they do it in different ways. Second, we shall observe how this file, comprising various documents, reflects the complex history of this property, the specific language games which are attached to it, and its internal organization around principles of the contiguity of properties and the succession of legal deeds, in order to secure the buyer's property rights.

\section{Documents established for all practical purposes}

Mrs. Sabbah's file comprises six contracts of final sale, two special powers of attorney, one house tenancy contract, and water and electricity bills. These documents do not relate to the same property. The real-estate transactions they account for sometimes relate to unfinished storeys, sometimes to built storeys, that is, apartments. Nevertheless, the parties who take part in 
these transactions are related to each other through the close proximity of their properties and the successive character of the contracts (cf. infra, section 2).

As for the contracts, they [1] put the transaction under God's protection; [2] are titled; [3] declare the sale final; [4] specify the identity of the signatories of the contract; [5] define the content of the object of the transaction; [6] stipulate the modalities of the transaction (exchange of a property for money); [7] specify the date of the contract's execution; [8] state everyone's responsibility vis-à-vis the Syrian administration; and [9] specify the conditions under which the sale took place and the contract can be annulled. Moreover, some contracts also [10] mention the payment by one of the parties of a fee to the broker and [11] account for the registration with the Ministry of Finance.

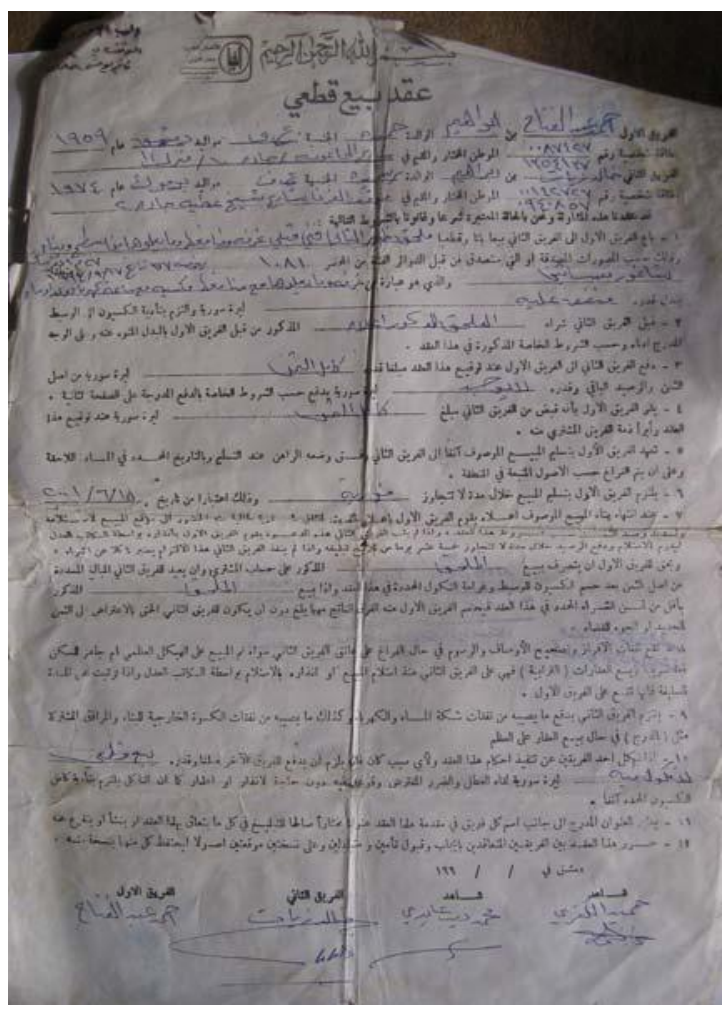

fig. 1: $2^{\text {nd }}$ contract of final sale (front)
In the name of God the Benevolent the Merciful [1]

Contract of final sale [2] [3]

The first party Ahmad ... The second party Khaled ... [4]

We have agreed upon the transaction ... according to the following provisions:

1 - The first party sold to the second party in a full and final way the extension situated ... in return for what was agreed upon.

/The first party/ committed itself to the payment of the commission to the intermediary person. [5] [6]

2 - The second party accepted to buy the extension ... in return for its balance ... [5] [6]

3 - The second party paid to the first party ... the sum of ...

The remainder ... will be paid according to the special conditions... indicated on page two. [9]

4 - The first party declares having received from the second party the sum of ... and has given the final discharge to the buying party.

5 - The first party committed itself to leave the estate... in its current condition...

6 - The first party committed itself to the payment of the sum ... immediately... starting from the date of $18 / 6 / 2001$. [6]

7 - When the building of the aforementioned estate is completed, the first party announces it ... If the second party does not answer, the sale is considered null and void ... [8]

8 - The expenses linked to the [Land Registry procedures] are owed by the second party... [The] taxes ... are owed by the second party ... [7]

9 - The second party shall pay the [subsidiary] expenses in case the construction of the sold estate is unfinished. [9]

10 - If one of the parties rescinds the contract ... it would be compelled to pay to the other party the sum equivalent to the value of a final sale ... [3]

11 - The address mentioned beside the name of each party ... is considered as the address ...

12 - This contract was made ... in two copies ...

witness / witness of the second party/ first party 


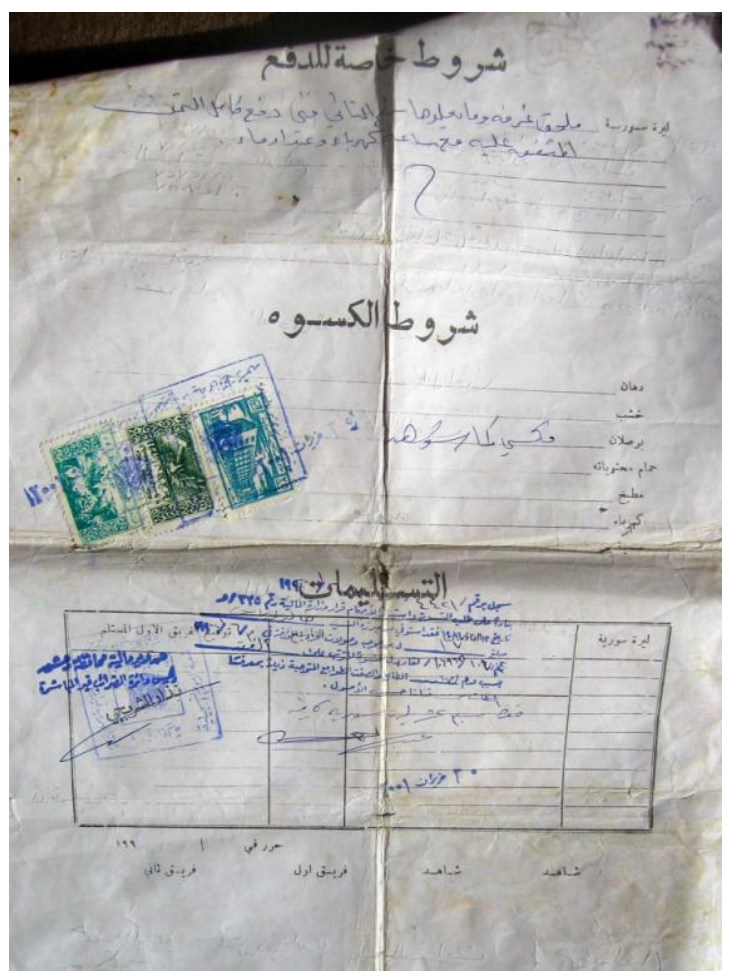

Special provisions for payment [9]

Syrian pounds an extension made of one room and what overhangs it, above the second floor, has paid the totality of the sum agreed, with the electricity meter and the water meter

Conditions of subsidiary work

Paint, wood, ceramic tiles covering as observed [9]

bathroom and content

kitchen

electricity

[illegible word]

Instalments

stamp of the Head Office of Indirect Taxes of the Ministry of Finance, 30 June $2001[11]$

Written 199

Witness / Witness / first party / second party

fig. 2: back of the $2^{\text {nd }}$ contract of final sale

The contracts are not all identical. In Mrs. Sabbah's file, the first one (see below) was written by an attorney, as indicated by the heading of the document and the comment: "written by myself" followed by his signature and stamp. In a preamble the attorney describes the estate which is concerned by the sale and then states the completion of the sale. In the next five contracts, there is neither any preamble nor the mention of the attorney's role. However, two witnesses have appended their signatures at the end of the deed: "in the full possession of our legal and judicial capacities, we have agreed upon this transaction". These five contracts are written on standard forms, available in ordinary shops. Some parts of the form are left empty, or are more or less completed. The back of the document offers the possibility to specify the conditions of payment, the inventory of fixtures and the timetable of instalments. These specifications are different in each case, although all the contracts describe the estate which is sold.

All these sale contracts present themselves as final and binding. In signing this document, the owner gives up all his rights on the estate to the buyer. The transfer of the property and the price of the transaction are the subject of two provisions stating the action accomplished by the two parties. The transaction is not registered in the Land Registry insofar as the property itself is not registered. Thus, the buyer's rights are not guaranteed by the Land Registry. However, the transaction is registered, as far as the first three contracts are concerned, with the Ministry of Finance, as indicated by the stamp on the back of the documents: this will give it legal force and will serve to testify to property rights. The fourth, fifth and sixth contracts are not registered with the Ministry of Finance. The transaction they refer to might be reinforced by the power of attorney given by the seller to the buyer, as is the case with the fifth and sixth contracts. There is, moreover, a handwritten note on these last two contracts, as well as on the third one, which 
stipulates this procedure indirectly when it characterizes the transfer of the property: "the sale consists of a special power of attorney."

The two powers of attorney completing the file also show repeated features like [1] a heading, [2] the civil status of the public prosecutor and of the beneficiary of the power of attorney, [3] the public prosecutor's statement and signature, [4] the description of the property concerned by the power of attorney, and [5] the number under which it was registered by the notary. Each power of attorney also defines precisely [6] the competences which have been delegated. Officially written by the public prosecutor, the power of attorney mentions, at the end of the document, [7] the signature, stamps and statement of the notary testifying to the respect of procedures and to the authenticity of the deed. Finally, it is dated [8].

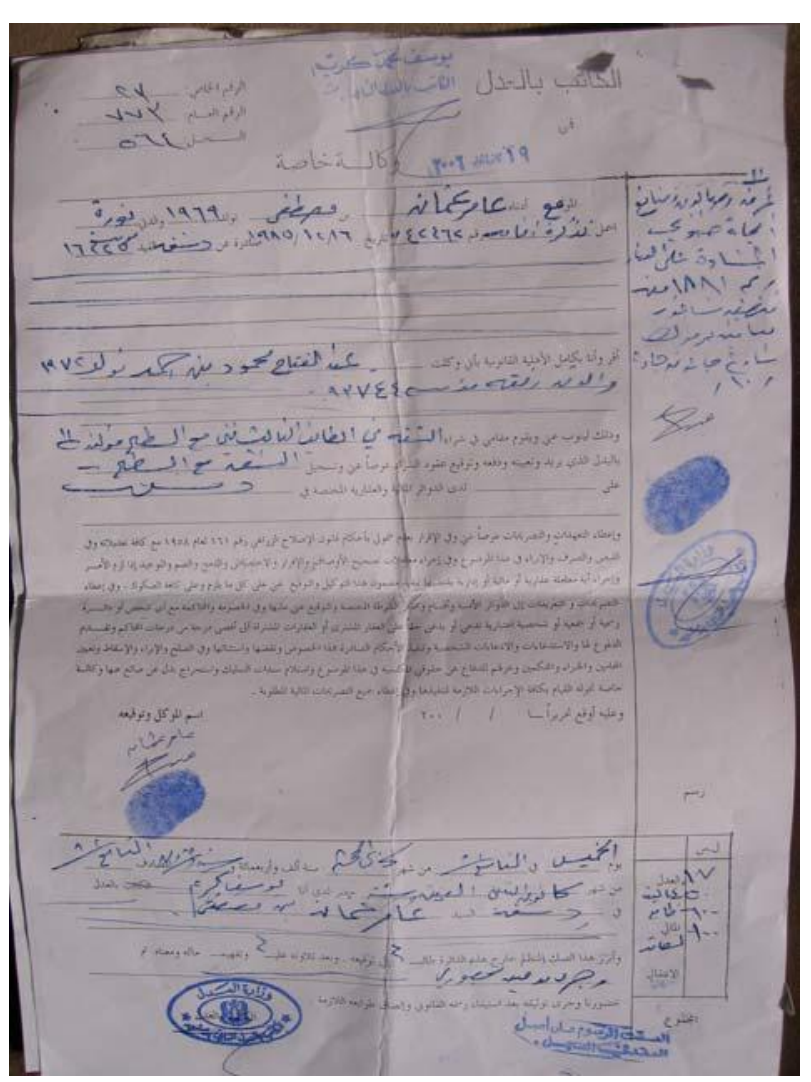

The notary

Special number 23 [5]

General number 773 [5]

Register 564 [5]

\section{Special power of attorney [1]}

19 January 2006 [8]

I undersigned 'Amer ... [2] declare ... having conferred power of attorney [3] to 'Abd el Fatah ... [2] to represent me ... in order to buy [description of the flat] [4], to ... sign the contracts ... and to register the flat ... with the competent financial and real-estate authorities ... [6] To commit ...; to declare that ...; to receive ...; to execute [real-estate, financial and administrative operations]; to sign ...; [to represent me] for any ... trial against ... [6]

Accordingly, I sign in a written form name and signature of the public prosecutor [3]

On Thursday... Mister 'Abd el Fatah ... presented himself before me... And he showed this document established outside the department and asked me to sign it. After having read it to him and having made him understand its consequences and meaning. The signing took place in my presence [7]

Registered after payment of the legal taxes and the required stamps...

fig. 3 : power of attorney associated to the $5^{\text {th }}$ contract

The text of these two powers of attorney forms is identical, and the handwritten parts are the same except for slight details. These powers of attorney concern the last two transactions and correspond to the last two contracts which were also kept by Mrs. Sabbah. There are two types of power of attorney: general, through which somebody confers powers to somebody else for any transaction that concerns him/her; and special, through which somebody confers powers to somebody else for any transaction concerning a particular property.

The powers of attorney enclosed in Mrs. Sabbah's file are special. The person who sold the property to Mrs. Sabbah conferred to her all the transactional powers concerning this property. In 
this power of attorney, as in any special power of attorney, the buyer and the seller do not appear as such: the buyer is the prosecutor and the seller is the person to whom the powers are conferred. The power of attorney aims at giving the appointed proxy the capacity to act vis-à-vis the said property as its owner. It gives the right to make transactions, not the right to ownership. So, one can raise the question as to why a power of attorney must be made by the seller to the buyer while normally the sale implies the transfer of all the rights bound to the property. This leads us to question what the power of attorney accomplishes formally and allows indirectly.

The power of attorney is a deed registered by the notary, who is an employee of the Ministry of Justice. It has an official character which affects the whole real-estate transaction. Since the sold property is of a certain type (i.e. a flat in a building constructed on rural land which is not divided into plots and belongs to the state), the transaction cannot be registered at the Real-estate Office. Hence the power of attorney. In other words, the power of attorney serves as a means to testify to a transaction that cannot follow a normal course. The same holds true for the registration with the Ministry of Finance in the first three contracts.

\section{The file establishing ownership: chronology, language-games and instructed action}

Mrs. Sabbah's flat is located in a building whose construction lasted more than ten years. The first contract dates back to 1996 and indicates that the building is made up of a ground-floor and one storey. The fifth contract, dating from 18 January 2006, concerns the third-floor flat and a room built on the fourth floor. Thus, three storeys have been added between 1996 and 2006. These contracts do not all concern the same property. However, they are linked to one another, not the least because they are all included within the same file. Two issues come to light in that respect: on the one hand, the existence of Mrs. Sabbah's property depends on the existence of the storeys on which it is built; on the other, it is only possible to testify to the ownership of Mrs. Sabbah's property on condition that one can establish the ownership right of the person from whom she purchased it. It is for these two cumulative reasons that she keeps the file of the successive contracts which lead to her ownership.

The close examination of Mrs. Sabbah's file makes it possible to account for three major features of this process: first, the chronology of the building and the transactions carried out on the different storeys; second, the inventory of the real-estate jargon and language-games; third, the description of the principles of the physical proximity of the properties and the successive character of legal instruments leading to the ownership of the flat, which bring together all the documents.

\section{The Chronology}

The inclusion of all these documents in one and the same file raises a question which can be answered through the examination of the many links which bind these documents together. Among these links, there is the succession of these documents in a chronology that led to the construction of the building in its present form and to the acquisition by Mrs. Sabbah of the ownership of the third-floor flat. Hereinafter follows the summary chronology which can be established on this basis.

The first contract, dated 8/12/1996, concerns the sale of one half of a storey suitable for development, of a surface area of $27 \mathrm{~m}^{2}$, on the second floor of a building comprising a ground- 
floor and a first storey of a surface area of $60 \mathrm{~m}^{2}$. The second contract, dated 18/6/2001, accounts for the selling of an extension of $27 \mathrm{~m}^{2}$, located on the third floor, and of the storey suitable for development above it, that is, a potential extension on the fourth floor. The third contract, dated $27 / 3 / 2004$, concerns the third-floor extension. The fourth contract, dated 18/1/2006 concerns the third-floor extension, plus the non-built storey above it. The fifth contract, dated 18/1/2006, concerns the same third-floor extension, plus the storey above it which is now built. Finally, the sixth contract, dated 5/4/2006, concerns the third-floor extension again, without any mention of the room located on the fourth floor. It is only through a discussion with Mrs. Sabbah that we learned this room belonged to her. This room is only partly built and its roof is made of sheet metal. Access to it is through the flat's kitchen.

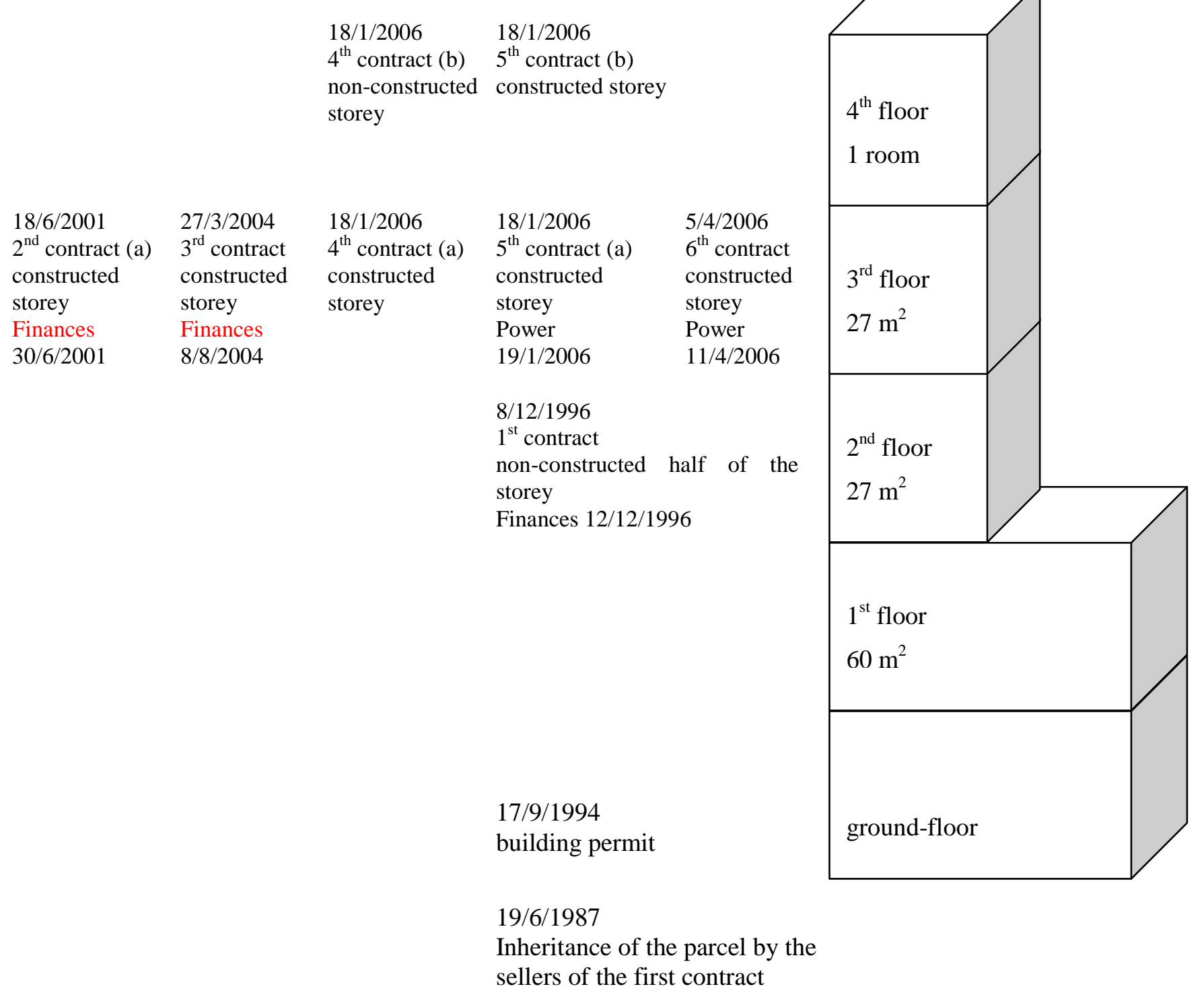

fig. 4: chronology of contracts and powers of attorney 


\section{Real-estate language games}

Real-estate and transactions regarding it are formulated with words. We will describe these words and their connections to one another, through what Ludwig Wittgenstein calls language games. These games accomplish the literary inscription of a material reality (Latour, 2002). They produce descriptions that aim at making things, people and actions enter the realm of categories acknowledged by the law. This is what lawyers know as the characterization process, the main feature of which is to be consequential. We will describe and analyse the main categorization elements of Mrs. Sabbah's file as used in contracts and powers of attorney, i.e., the land, the building, the storey and the flat.

References to the land in the documents of this file mix geographical commonsense and legal administrative terminologies. Some of the contract forms indicate that the real-estate is of a mulk type, which points to private ownership. The preamble of the first contract specifies that the plot of land is situated "in Damascus, camp of Yarmuk, al-Ja'awna street, alley (jâdda) number /10/ ... on plot ( 'aqâr) number /1081/ Shaghur Basatin." The first half of this account is an itinerary to follow. It starts from a general location: Damascus, and ends with the precise location of the plot of land, alley number $/ 10 /$, which one reaches as if we were taking a taxi, via al-Ja'awna street. The second part of this account locates the land with the technical words specific to realestate administration: the real-estate number (1081) and a name (Shagur Basatin), sometimes preceded by the mention "district" (mantiqa), which designates a specific real-estate entity. ${ }^{1}$ The next contracts are much briefer regarding the description that locates the land: geographical references are no longer indicated; only the administrative terminology is kept; the real-estate number is mentioned, but there is another term corresponding to it, that of "report" (mahdar). The association of a number (1081) and a real-estate name (Shaghur Basatin) shows that the word "report" refers to the real-estate and, therefore, this number has a real-estate nature.

The building in which Mrs. Sabbah's property is located is not always mentioned in the documents of the file. When mentioned, two types of terminology are used for the designation of the land. The administrative type copies municipality terminology. It mentions "the building (binâ') known as the house (manzil) number /11/ according to building permit number /177/." The number (11) associated to the "house" refers to a document, i.e. the building permit, which is not included in the file. It testifies to the registration of the building in municipality records, whereas, as we already know, the real estate plot on which it is located is itself registered in the Land Registry. The second type of terminology is related to commonsense. The term "house" (manzil) is used in a domestic more than a legal sense. Moreover, the building is designated in some documents as the "Idriss Building", which refers to the original owner of the plot of land.

All the properties the successive contracts and powers of attorney refer to are located within the same building, in a vertical axis, according to the constructed or non-constructed nature of the surface area which is sold. If the property is not built, the documents speak of a "storey" (sath);

\footnotetext{
${ }^{1}$ The third contract does not use the word "district", but only the predicate "real-estate" (al'aqariyya) to designate the administrative entity. The adjective replaces the substantive it normally predicates.
} 
the floor of which is itself specified with regard to the construction on which it is built: either it is above it ("what overhangs it": "ma ya "luha"), or it is situated above ("above the storey": "zahr al-thani fanni" and "sath al-thani fanni"), or it is associated with it ("with its storey": "ma "a sathiha" or "ma' a al-sath). However, in the first contract, the storey where the surface property is located is not only given in relation to the storey situated below; it is also complemented by a reference to the surface situated above: "half the storey of the second floor" (nisf sath al-tabiq al-thani fanni). When it is constructed, a property is situated vertically in the building by reference to the floor, either implicitly ("the third": "thalith fanni") or explicitly ("of the third floor": "min al-tabiq al-thalith fanni"). Thus, the term "fanni", which means literally "technical", when associated with a number, refers to a floor, with or without the prior mention of the term "floor" (tabiq) itself. Note that without the term "fanni", the association of the number with the word "floor" would have another meaning, that is, it would designate the floor situated below, the ground floor then becoming the first floor.

The property which is sold is sometimes described, when it is developed, using a general term like "extension" (mulhaq) or "flat" (shaqqa). The content is sometimes specified by the introduction of the formula "made of" ( $m$ ' allaf $\mathrm{min}$ ), through the adjunction of words linked together with the conjunction "and", or simply through their juxtaposition to one another. In other contracts, the terms "extension" or "flat" are just not mentioned. The composition of the property can be given directly - "a room" (ghurfa), a living room (salun), a bathroom (munfa 'at), with its storey ( $m a^{\prime} a$ sathiha) - or indirectly, through the reference to the number of the registered plot on which the building was built, so that the constructed property and the plot on which it was constructed are confused : "... real estate 1081 of the district Shaghur Basatin which consists of a room, a living room and a bathroom" (al-mahdar /1081/ min mantiq Shaghur Basatin wa-lladhi huwa 'ibaratan 'an ghurfa wa salun wa munfa'at). Note that the term "extension" becomes a "flat" when a room is appended to it. Then, the property is formulated in the following way: "a flat... with its storey... there is a room on the storey (ghurfa 'ala sath)". "an extension... a room and a bathroom and the building (bina') overhanging them" is once mentioned. Sometimes, the surface area (masaha) of the property, i.e. $27 \mathrm{~m}^{2}$, is indicated, as well as its orientation- "South" (ittijah janubi, janubi, or qibli). The contracts also specify the fact that there are water and electricity meters, which indicates the state of completion of the property. These meters are also used for legal recognition of the property.

There are language games operating in the description of the property that is sold. The notion of language game is borrowed from L. Wittgenstein (1963) and refers to the fact that words take their meaning from their association to one another and through their context of use. A specific language corresponds to any activity with which people are familiar. The meaning of words is not given outright; it comes from words which, once combined, look similar to those other combinations specific to the many domains of life and language, like the law. Language games can share a family resemblance which shows the type of domain to which they belong. The notion of family resemblance is also borrowed from Wittgenstein, and it means that words associated with an activity share a number of features and therefore often constitute a lexical field. The many language games are learned through the familiarity people acquire with their environment, its working, the forms of life to which they are associated, "the social practices of a linguistic community which are so deeply rooted that the speakers do not even think about it" (Dupret, 2006 : 63 ; Schulte, 1992 ; Wittgenstein, 1961). 
Bruno Latour explains that in the case of documents, language games achieve the literary inscription of a material property. He stresses the transformation the writing exercise operates on the primordial object, and raises the question of the selective character of writing which proceeds through shortcuts and hides the mechanisms operating in that very activity (Latour, 1996: 43). Literary inscription also has the capacity to establish facts and to make them enter into categories so as to become useful for all further practical purposes. This especially holds true in the domain of law. The writer of a contract, for instance, elaborates it for all practical legal purposes (Dupret, 2006: 249). This is often done by obscuring the biographical details of the object of the contract and of the practical conditions of its writing (ibid.: 162). Focused on its future use more than its past, a contract testifies to the transaction which it will perhaps confirm later on.

As for Mrs. Sabbah's file, the language games we described produce legal forms through a process of inscription, that is, through the transformation of a real estate materiality into a literary reality. The organization of the document into several provisions, the use of stereotypical expressions and particular formulations, and the use of template forms, all give it the form of a contract and denote its legal nature. However, it would be simplistic to say that a legal document only reproduces pre-existing forms: although the legal document is the outcome of a process of form-setting, (mise en forme), it cannot be reduced to the pure product of legal formalism (Latour, 2002: 181). Producing forms is also the capacity to produce effects, e.g. legal.

The literary inscription of a material property is achieved for all legal practical purposes. Regarding real estate, this involves producing a document testifying to the transaction and making it possible to be opposed in court. In our case, the language games in the document reveal the informal nature of the property. Indeed, it is through the association of words familiar to people dealing with real estate - words with a family resemblance - that we know it is not only about real-estate law, but also a very specific, though not uncommon, form of this law, that is, real-estate law in informal neighbourhoods.

It is clear that the documents in Mrs. Sabbah's file relate to a real estate. An element of the description of the property is given, while it does not seem necessary, to complete the meaning of another word and to attach it to the family "real-estate". The word "mulhaq", which is a predicate meaning "added" or "annexed", acquires the value of a substantive, and its meaning "surface built on the last floor of a building" comes from its being inserted in a context and associated with other words. Moreover, the repetitive use of the word gives it a conventional character, so that it can be understood without its being directly associated with other elements of the real-estate vocabulary and its meaning explained. In the same way, the word "mahdar", which designates what has been recorded, the page of the Land Registry, acquires the meaning of land parcel, then of built property, because of its association with other words. The word has taken on a new meaning through a succession of shortcuts and ellipses.

The fact that the documents of Mrs. Sabbah's file concern a real estate located in an informal neighbourhood is never mentioned directly. Indeed, the absence of any registration in the Land Registry is not explicit. The specific character of this estate is nevertheless expressed through a series of linguistic expressions. This is also the case with the use of terminology pertaining to commonsense, like "Idriss estate". The use of the term "extension" is another indicator. In Land Registry vocabulary, it refers to a room on the last floor jointly owned by all the owners of the building, which as such cannot be sold. However, in the language game of informal settlements, 
it refers to the flat on the last floor, which is privately owned. Lastly, the way the property is vertically located in the building, e.g. through the use of place adverbial complements, situates the construction in an informal zone: the property is located through its relationship with another property and not according to its Land Registry number. Physical topology replaces bureaucratic registration.

We see that language games formalised a material reality into a written document, bestowed it a legal status and revealed the particular character of the properties relating to the transactions. These properties which we call "informal" are designated in Arabic by the word "mukhalafat". This encompasses the idea of infringing the legal order of things. It does not amount to illegality as such, but the contradiction between the agricultural nature of a plot of land and its development. The expression does not refer to any given category per se, but to an array of practices, habitual and vague, associated by the same language game.

\section{Close proximity of properties and succession of contracts: the regressive reading of the file}

It has been noted that the property which is sold in the last contract is not the same property which was sold in the first: whereas it was initially only half a storey, in the end a complete apartment is the subject of the transaction; whereas it was only a storey on which the buyer implicitly had the right to build, it ends up as a built apartment. It is the way the file is constituted that allows Mrs. Sabbah (as it allowed all the former owners), to establish the property's history and origin. Because the building is not registered with the Land Registry, there are good reasons to keep all the documents testifying to the transactions related to it. The file in which the documents are assembled reveals what the documents hide: the property's origin. It is through the detailed and regressive reading of the file in its entirety that it is possible to describe the many links between the documents and to establish the proximity of the properties and the chronological succession of the contracts. We saw how the documents were written for all practical legal purposes; now we shall examine the nature of the reading of these documents and of the file they constitute.

The reading of texts, documents and files consists of what Livingston calls instructed action. This notion refers to the fact that reading is an achievement relating two parts (or Lebenswelt pairs): the text and its understanding. The text must be read as a descriptive account, a guide for the action of reading. The reader develops a method of reasoning through his/her leaning on the text's clues, so that he/she can give a coherent meaning to what is read. Understanding a sentence calls for the reader's skill and capacity to mobilize the background knowledge necessary to make sense of the clues. Livingston speaks of a community of readers and of a background knowledge shared by this community. In that sense, reading is a social phenomenon revealed through people's capacity to understand a text.

Recognizing that legal documents constitute a file is a first reading clue. Guided by textual instructions, the reader relates the many different elements constituting the file that are capable of producing some legal aspect. This is what Latour (2002) calls "bringing a file to maturity". A legal practitioner will read from within the text the information which proves useful for the accomplishment of his work (Dupret, 2006). The reader's practical reasoning and capacity to call 
upon background knowledge make it possible to understand what is said and to pick out relevant information for the purpose of the ongoing activity, that is, for all practical purposes.

The duplication of a mistake in the description of Mrs. Sabbah's property presents a good example of this mechanism of reading for all practical purposes. It gives a clue as to the way a document is read. This mistake concerns the parcel's number on which Mrs. Sabbah's property is located. The mistake appears in the fifth and sixth contracts, together with the powers of attorney which are associated with them. The fifth contract's first page indicates parcel number "1081", whereas the same contract's second page mentions "1881". The power of attorney associated with it as well as the sixth contract (and the second power of attorney) duplicated the mistake. This shows that the person who wrote the power of attorney attached to the sixth contract was concerned mainly with the reading of the fifth contract's second page, the information of which it reproduces. In the same way, the notary who registered the two powers of attorney was exclusively interested in the fifth contract's second page, so that he did not pinpoint the mistake that was accidentally introduced (cf. infra fig. 7).

In order to understand Mrs. Sabbah's file one must go through the instructed reading of all the documents and the file. Contracts and powers of attorney are forms, except for the first contract, which guide the reader in his/her reading work. The handwritten parts, filled in according to the writer's interpretation of the form's instructions, constitute further clues for the reader, i.e. the elements relevant for the establishment of the contracts' succession and the contiguity of the properties of the transaction. They give details regarding the civil status of the signatories of the contract, the description of the property, and the date of the transaction. The succession of sellers (X sold to Y, Y sold to $\mathrm{W}, \mathrm{W}$ sold to $\mathrm{T}$, etc.) which can be established by the reader of the file through practical reasoning is a clue as to the historical succession of the contracts. The third contract's second page establishes the succession explicitly: "the sale took place according to $\mathrm{Mr}$ [T]'s sale contract, which was certified on 30 June 2001 under Number [N1]; he bought it from $[\mathrm{X}],[\mathrm{Y}]$ and $[\mathrm{Z}]$, according to the contract certified by the Damascus Tax Office under Number [N2] dated 12/12/1996."

Close study of the first contract allows us to observe the pair text/instruction for reading. It is organized in three parts. The first part is clearly established: it presents the signatories of the contract. The second part of the contract, i.e. its preamble, groups several informational elements presented as the terms of an equation. They are bound together, within the same paragraph, through logical expressions: "considering X, Y and Z, this agreement was reached". First, there is a description of what is owned by the first signatory to the contract: he is the owner of property X. Second, the second signatory to the contract makes clear his wish to acquire a part of the property (half a storey). Third, the first signatory's intention to sell this very storey is made explicit. Fourth, it is said that the agreement is reached following the provisions indicated in the third part of the contract, which stipulates the rights and duties of each signatory.

The preamble of this contract indirectly gives the origin of the ownership right of the property. It is grounded on the reader's practical reasoning, which seeks to read the file coherently. The seller owns the property which is the object of the transaction "in conformity with the building permit [...] issued by the local committee of Yarmuk camp", through inheritance. The mention "Yarmuk camp" and the reader's background knowledge make it possible to understand that the ownership is of a particular nature. This interpretation is confirmed by Article 6 of the contract, 
which reads: "The two contracting parties agree [...] not to breach [...] the rights of Refugees Foundation on the land on which the storey is located." Although the origin of the deceased person's property is not specified, it can be deduced from the reader's background knowledge: it is the Foundation for Palestinian Refugees that attributed the parcel, that is, the permit to live in a given place (izn sakan).

Moreover, the property is not registered as real estate in the Land Registry. It is built on part of a Land Registry parcel which is larger than the property itself. This can be deduced from the use of the preposition "on": the property is not the parcel itself. Another point is added: the property that is sold is not the totality of what the first party declares as his ownership, but only part of it, i.e. a storey, to which no parcel number is given. The contract makes a distinction between the ownership of a storey and the ownership of the land, the latter belonging to the Foundation for Palestinian Refugees. In other words, we can say that the reader's practical reasoning and his affiliation to a community of readers helps him understand the meaning of the text.

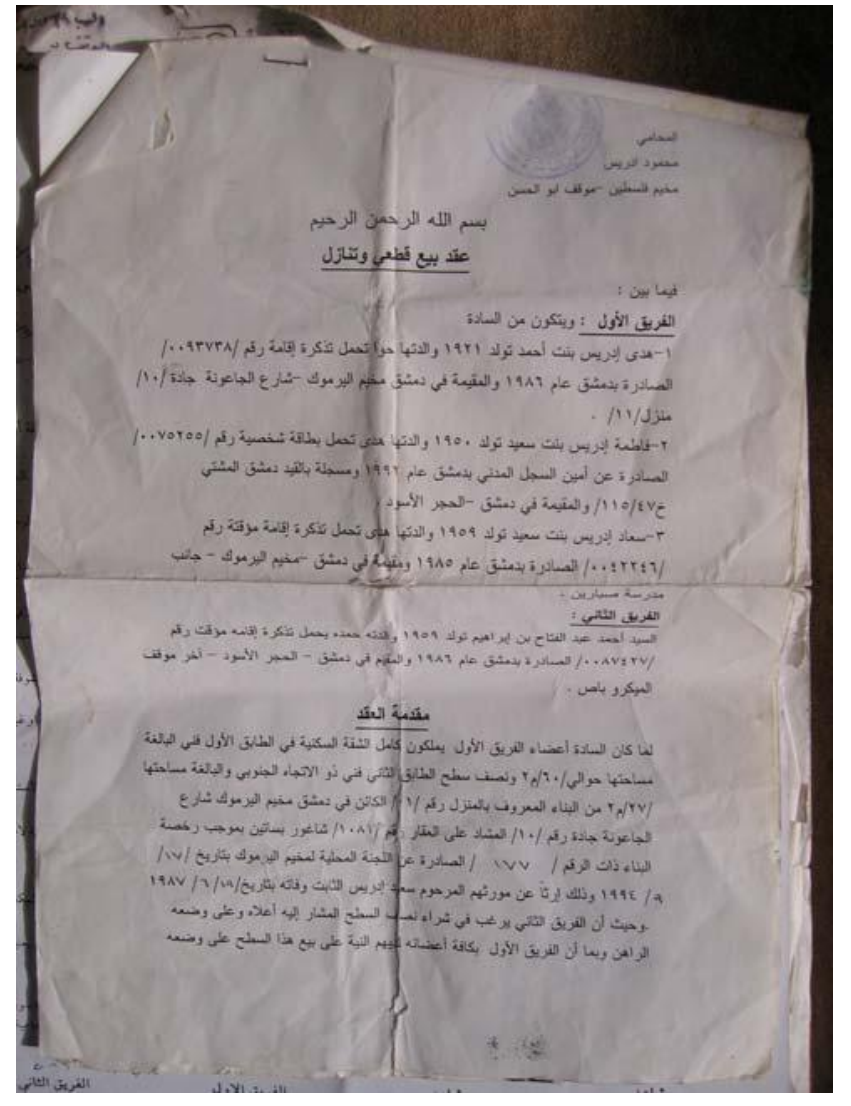

fig. $5: 1^{\text {st }}$ contract of final sale
Attorney Mahmud Idriss, Camp of Palestine -Abou Hassan In the name of God the Benevolent the Merciful Contract of final sale and cession

Between:

The first party is the following women ...

The second party Mr Ahmed...

Preamble of the contract

Considering that the women constituting the first party own the totality of the apartment on the first storey, whose surface area is approximately 60 square meters and half the storey of the second floor facing the south, whose surface area is 27 square meters, of the building known as building /11/ located in Damascus, Yarmuk Camp, al-Ja'awna street, alley Number /10/, built on real estate Number $/ 1081 /$, Shaghur Basatin, in conformity with Building permit Number /177/ issued by the Local Committee of Yarmuk Camp, on 17/9/1994, in inheritance of the testament's author, the late Mister Idris al-Thabat, whose death was established on 19/6/1987.

Considering that the second party wishes to purchase half the storey of the abovementioned floor in its current state

Considering that all of the members constituting the first party intend to sell this storey in its current state, this agreement, which guarantees the rights of both signatories, in full possession of their judicial and legal capacities, was concluded as follows: 


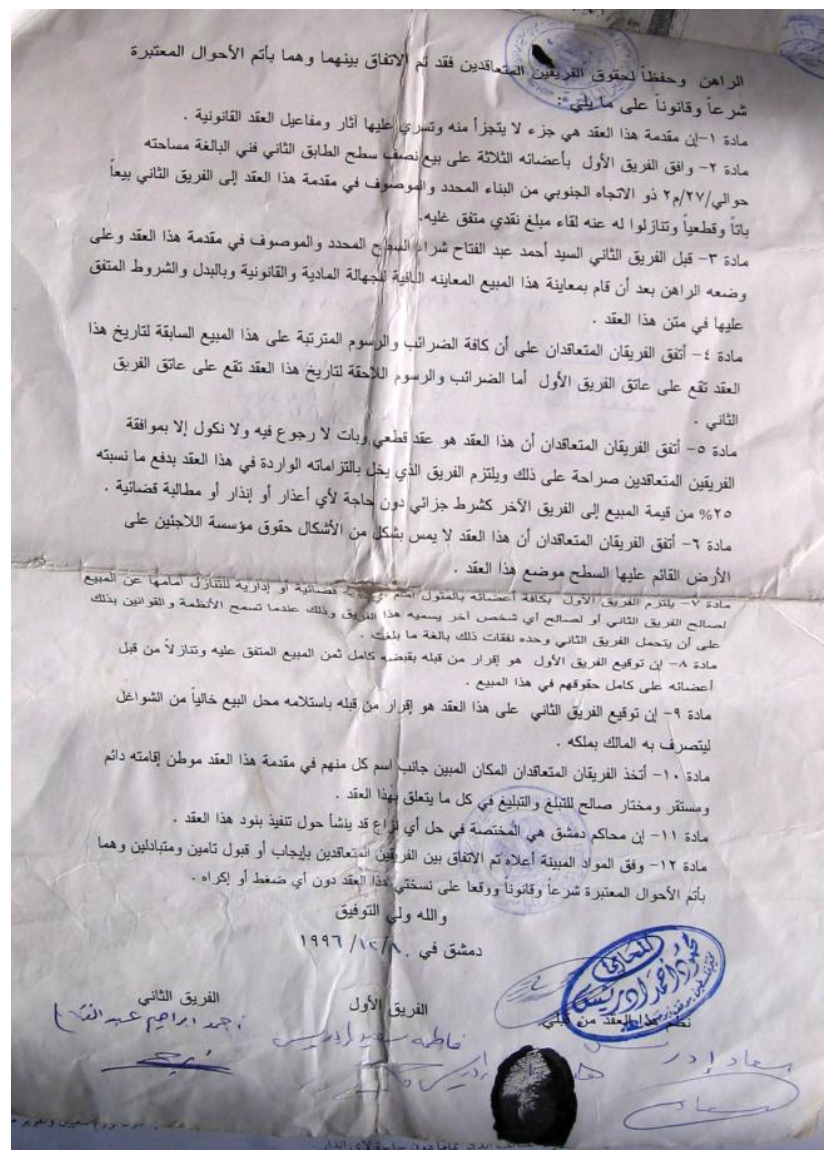

Article 1 - The preamble of this contract is ... an integral part hereof ...

Article 2 -The first party ... has accepted to sell half the storey of the second floor for the sum agreed upon

Article 3 - The second party ... has accepted to purchase the storey ... after visual examination of this property...

Article 4 - The two contracting parties agree that all taxes ... before the date of this contract are payable by the first party, whereas future taxes ... are payable by the second party.

Article 5 - The two contracting parties agree that this is a final contract ... The party who breaches the agreements mentioned in this contract accepts to pay ... as a penalty ...

Article 6 - The two contracting parties agree ... not to breach ... the rights of the Foundation for Refugees on the land on which the storey is located ...

Article 7 - The first party ... shall present himself before a judicial or administrative department to proceed ... with the transfer of the property ... when the regulations and the laws so permit ...

Article 8 - The first party's signatures testify [to receipt of the sale price and the transfer of the property]

Article 9 - The second party's signature testifies [to receipt of the property] for [the price] of sale ...

Article 10 - The two signatories have designated ... the place of permanent residence ... for everything related to this contract.

Article 11 - The Damascus courts are ... competent in case of conflict ... Article 12 - The two signatories have accepted this agreement ... and signed this contract ...

With God's blessing

Damascus, on 8/12/1996

This contract was written on my behalf [attorney's stamp + signature] [name of the parties + signatures / fingerprints]

fig. $5: 1^{\text {st }}$ contract of final sale (second part)

The last contract, unlike the first, does not make any logical connection between being the owner and selling one's property. It mainly states the transfer of ownership from the seller, whose title is not questioned, to the buyer. The seller's right is taken for granted, without any need to mention its origin. The first provision indicates that "the first party has sold to the second party ... a room ...", whereas the second provision confirms that "the second party has accepted to purchase the flat ..."

Most of the contracts and powers of attorney make no reference to the origin of ownership. It is only through the instructed reading of the file that one can establish the connections between the different documents, give some coherence to the collection of these documents in one and the same file, and trace back the history of ownership. The impossibility to register in the Land Registry properties located in informal neighbourhoods led people to proceed indirectly and to use strategies permitting them to claim their ownership rights.

\section{Conclusion : The documentary mechanisms of real-estate security}

The detailed description of Mrs. Sabbah's file and of all its documents allowed us to identify and understand the various elements of real-estate ownership and the complex relationships they have with one another. We saw how the file's documents were written for all practical legal purposes, and that language games formulate the property and the real-estate transactions concerning a property located in an informal neighbourhood. It is the instructed reading of the file, the reader's 
practical reasoning, and background knowledge that made it possible to make sense of these documents. The file's documents are constituted so as to secure ownership, the origin of which is fragile. The practice of the law and its procedures, of which the file's documents are an expression, are several instructed actions, that is, usages dictated in a more or less constraining way by the norms to which people refer for the sake of securing their ownership and its authenticity. In other words, the writing of contracts, their registration with the Ministry of Finance and the use of powers of attorney certified by a notary are used as means which testify to a transaction that could not follow a normal course. 


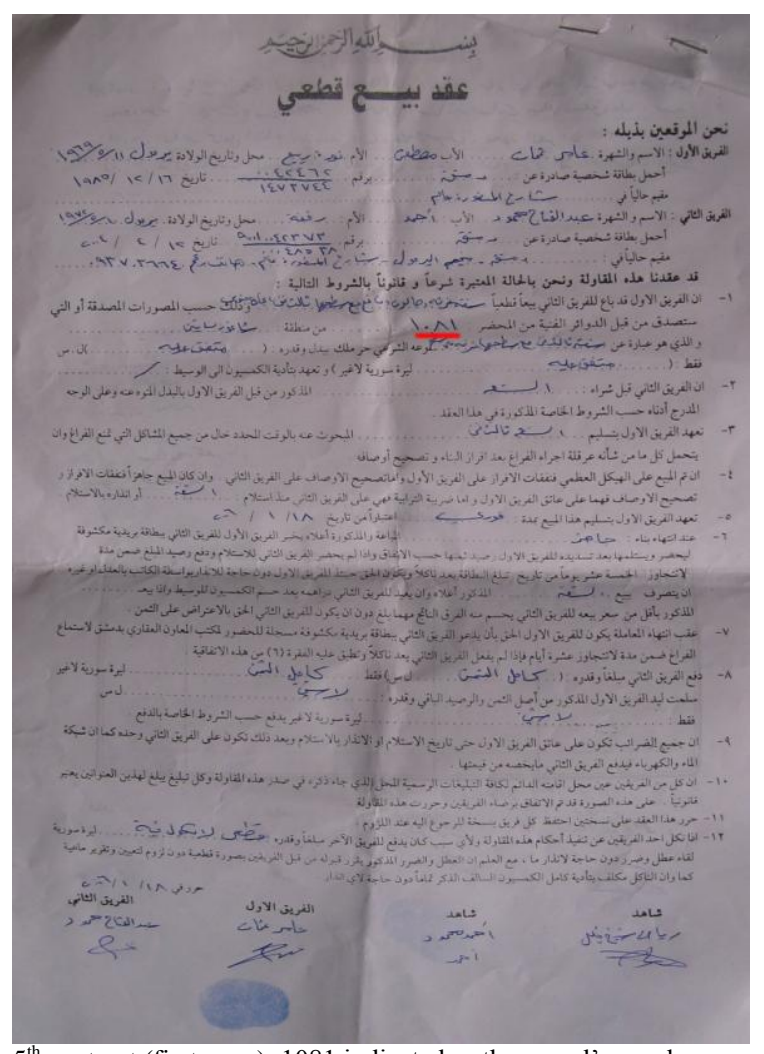

$5^{\text {th }}$ contract (first page): 1081 indicated as the parcel's number

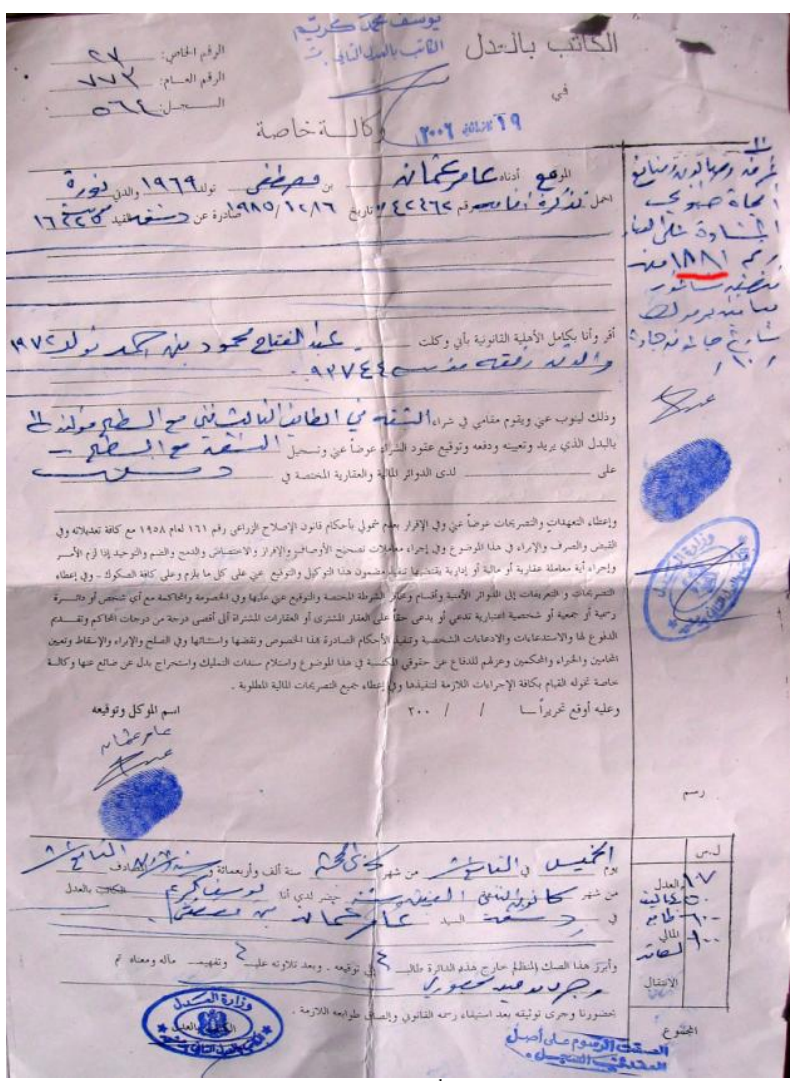

Power of attorney associated to the $5^{\text {th }}$ contract: 1881 indicated as the parcel's number

fig. 7: tracing the mistake concerning the parcel's number

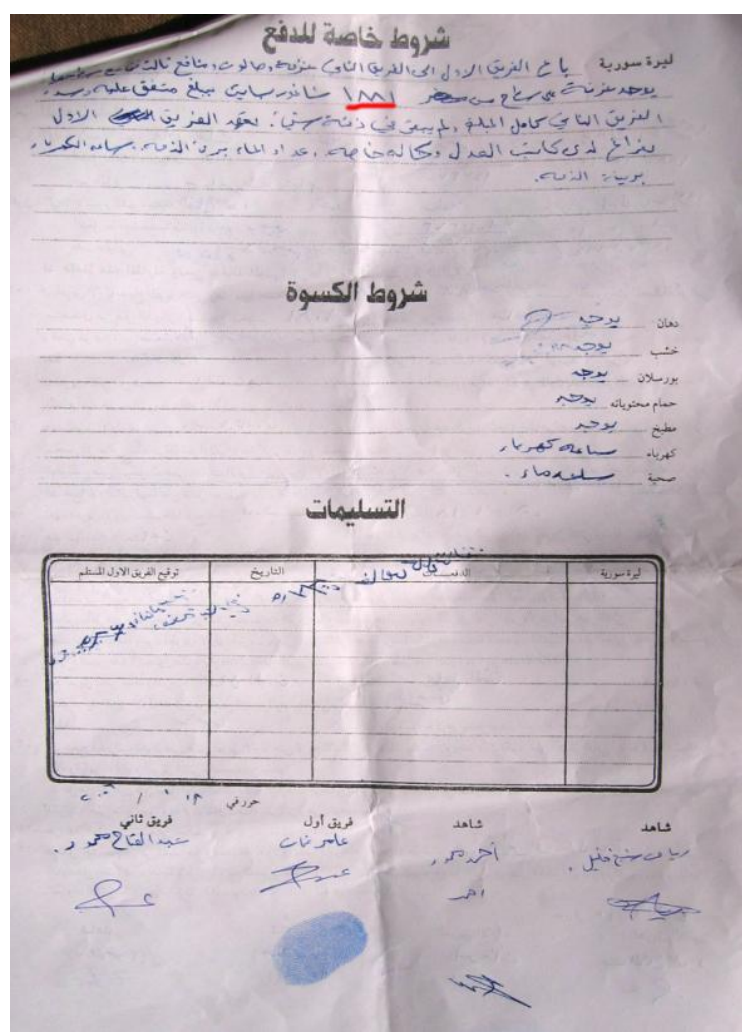

$5^{\text {th }}$ contract (second page): 1881 indicated as the parcel's number

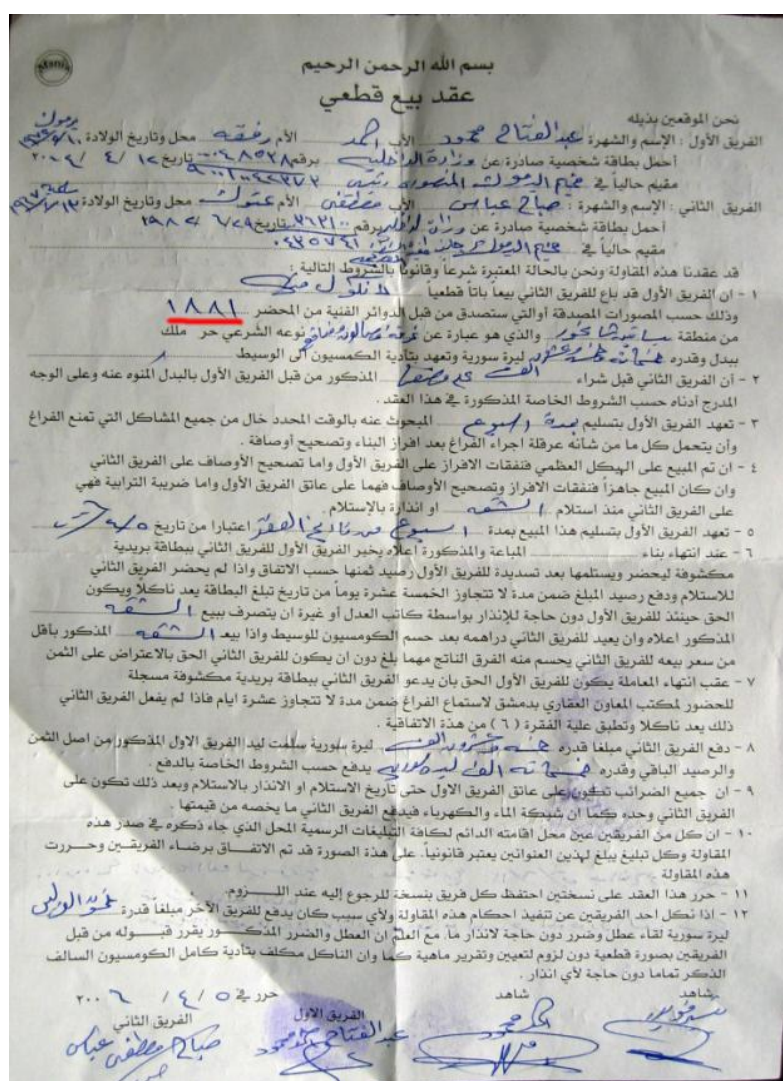

$6^{\text {th }}$ contract: 1881 indicated as the parcel's number 


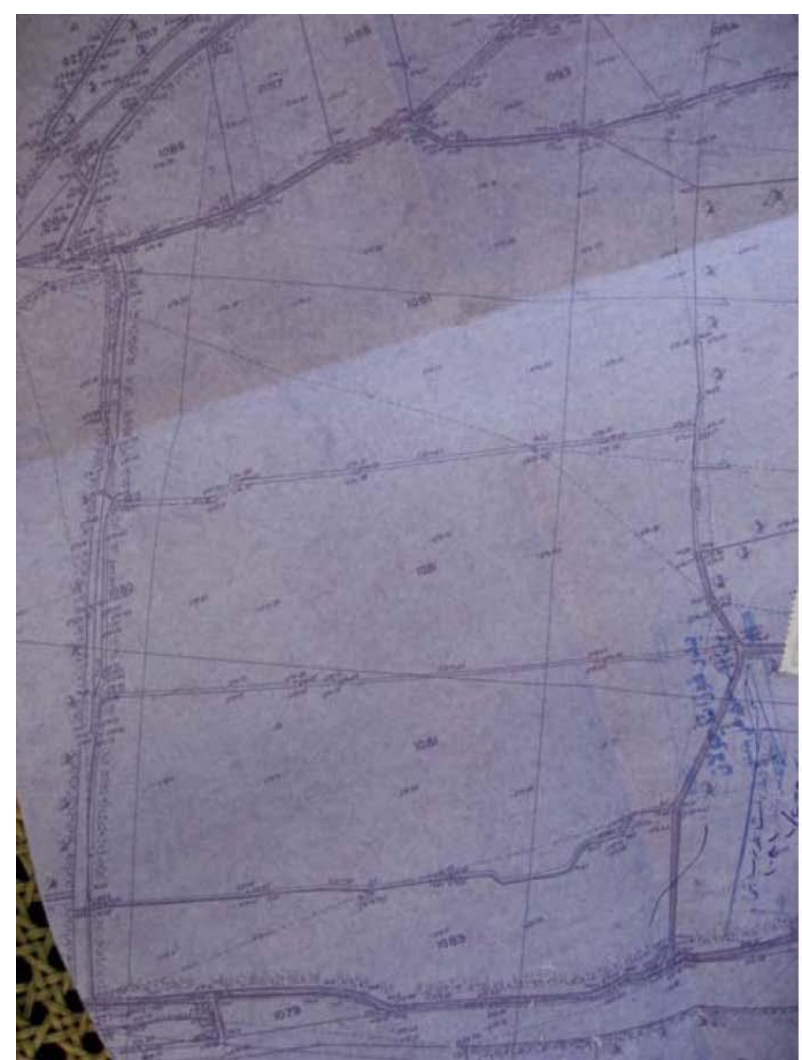

Fig. 8: Land Registry plan of Parcel 1081 District of Shaghur Basatin

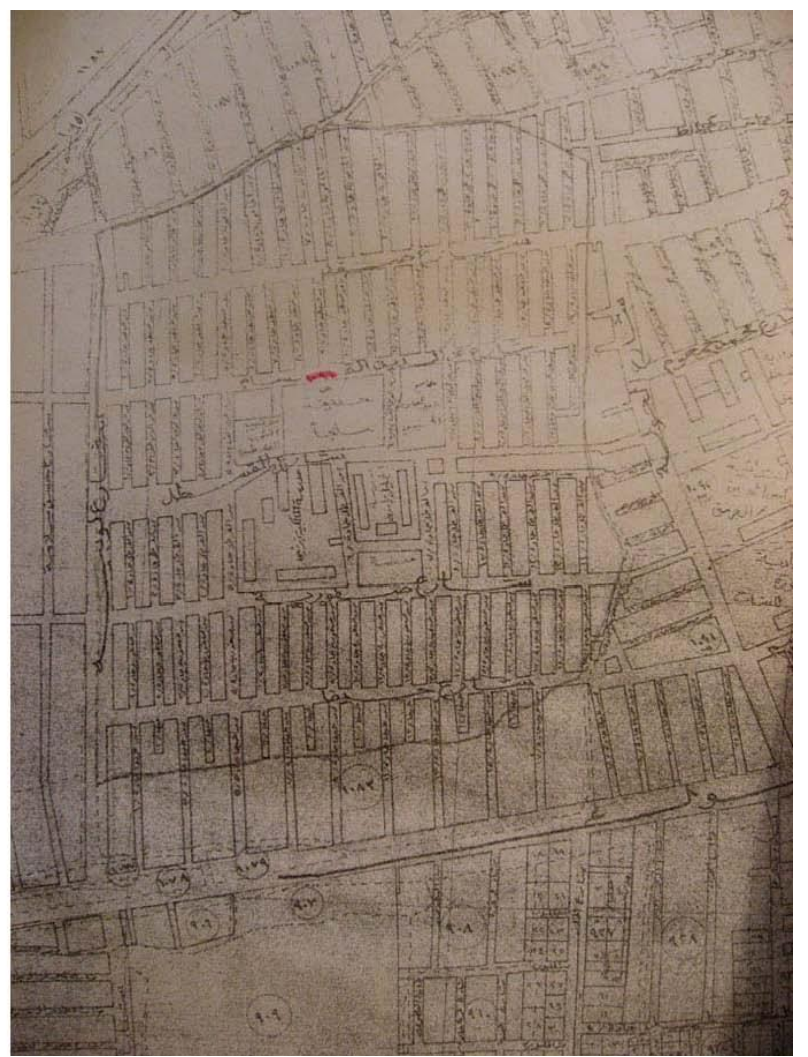

Fig. 9: Map of the Local Committee of Yarmuk: buildings on Parcel 1081 